\title{
Effects of Tennis Training on Personality Development in Children and Early Adolescents
}

\author{
Erdal Demir ${ }^{1}$, Gülşah Şahin ${ }^{1}$, Uğur Şentürk ${ }^{1}$, Halide Aydın², Mustafa Altınkök ${ }^{3}$ \\ ${ }^{1}$ School of Physical Education and Sport, Çanakkale Onsekiz Mart University, Çanakkale, Turkey \\ ${ }^{2}$ Faculty of Medicine, Çanakkale Onsekiz Mart University, Çanakkale, Turkey \\ ${ }^{3}$ School of Physical Education and Sport, Akdeniz University, Antalya, Turkey \\ Correspondence: Erdal Demir, School of Physical Education and Sport, Çanakkale Onsekiz Mart University, Terzioğlu \\ Campus, 17100, Çanakkale, Turkey.
}

Received: January 26, 2016 Accepted: February 27, 2016 Online Published: March 14, 2016

doi:10.11114/jets.v4i6.1334 URL: http://dx.doi.org/10.11114/jets.v4i6.1334

\begin{abstract}
The objective of this study was to investigate the effects of a 12-week basic tennis training program on the personality development of early adolescents aged between 9 and 11 years. The research methodology consisted of a single group pre-test/post-test design implemented with a total of eight volunteer children (three boys and five girls). The Personality Inventory (PERI), a data collection tool used to quantify (openness to experience, sense of responsibility, extraversion, compatibility, emotional balance). The mean calculation for each personality trait is provided in the form of descriptive statistics while the Wilcoxon test was used to identify differences between the pre- and post-tests. In conclusion, the research team observes that by improving early adolescents' openness to new experiences, tennis training facilitates the development of related characteristics, such as individuality, well-roundedness, ability to generate new ideas, creativity, flexibility, optimism, even temperament, low anxiety, attention to detail, discipline and ability to plan.
\end{abstract}

Keywords: children, adolescents, personality, tennis

\section{Introduction}

Personality is one of the classic and most comprehensively studied subfields of psychology (Yanbast1, 1996). It is defined as the unique, relatively long-term and stable modes of behavior of individuals (Hasirc1, 2013).

Adolescence is an important period of transition during which children need to develop the skills necessary to function as healthy adults able to solve problems, but is also a period during which psychological problems leading to negative behavior may emerge (Fields \& Prinz, 1997). The World Health Organization (WHO) defines the period of adolescence as between 10 and 19 years. However, since onset and duration vary according to sex, individual and societal factors, the period has been subdivided into three parts: the early adolescent period (10-13 years), middle adolescent period (14-17 years) and late adolescent period (18-21 years) (Özcebe, 2002).

Adolescence involves hormonal, physical and pubertal changes. These changes are readily observable, and adolescents may experience shock and anxiety over rapid physical changes or may, for example, exhibit emotional outbursts around others. They may also feel misunderstood or disliked, and in some cases even try to harm themselves (Özcebe, 2002). During this period developmental problems may be experienced relating to identity and value formation, as well as difficulty with responsibility and self-acceptance. These issues are readily observed among early adolescents, especially those from lower socioeconomic backgrounds (Dinçel, 2006). Other research has also suggested that antisocial behavior among early adolescents is more commonly observed in males (Endresen \& Olweus, 2005).

For adolescents, who are experiencing physical and psychosocial changes, a reliable and supportive environment should be created. They should be provided with information and services relating to mental and physical health that focuses on preventive and developmental support. In the US, for example, the American Medical Association has published a 23-point "Preventive Services for Adolescents" list of recommendations, one of which is, "Seek guidance on the benefits of sport and exercise and encourage regular exercise" (see Özcebe, 2002). With this in mind, we may hypothesize that sports training programs such as the one being tested here may facilitate the development of social and decision-making skills among adolescents, helping them to ultimately live happier lives as healthy adults (Dinçel, 2006). 
Personality development in children and adolescents is affected by many factors, from genetic predispositions to formative experiences (Celestin-Westreich, Celestin \& Ponjaert-Kristoffersen, 2013), and from nutrition to culture. Ingram and Price found that positive and negative personality development in children is a key indicator of future success, social relationships, educational achievement and lifestyle (see Shiner \& Caspi, 2005).

Some problems are encountered during the process of assessing personality in children and adolescents. These include validity of data collection tools and their personality assessment correlations, as well as conceptual problems related to personality, self-assessment and ongoing development (Poropat, 2014).

In recent years a frequently asked question has been, "Does sport affect development and personality formation?" Or, "Is there any relationship between sport and personality?" Studies in the field of "personality and sport" have not reached conclusive results but some scientists hypothesize that individuals choose sports suited to their personality, then assume success, while others hypothesize that individuals cultivate personality traits appropriate to the sport they have chosen (Hasirc1, 2013). The former was summed up by Martens as, "Sport is effective on personality," and the latter as, "Individuals beginning sport do sport because they are different" (see Bayer, 2003).

There are many studies on topics relating to the effect of sports training or nutrition on personality development in adolescents and children. For example, one study of nutrition suggests a positive correlation between fruit and vegetable consumption and the personality trait of openness to experience, and another draws a positive correlation between vegetable consumption and the trait of compatibility. Similarly, a positive relationship was identified between the personality trait of extraversion and participation in a sporting activity (Bruijn, Kremers, Mechelen \& Brug, 2005). Training provided at summer sport schools for 8-12 year olds has been shown to positively self-esteem (Korkmaz, 2007). A study by Coatsworth et al. (2005) on the correlation between recreational activities and identity experience among 493 adolescents in the USA, Chile and Italy, and another by Gilman, Meyers and Perez (2004) on the effects of structured extracurricular activities on adolescents, have both concluded that planned and programmed activities completed with a stated aim had a positive effect on identity formation and the cultivation of a sense of self. According to another study, sporting activities play a role in the physical development of 11-12 year olds, significantly affecting height and weight development (Soğat, 2007). Stuij (2015), in research assessing the effect of sporting environments on socialization according to lifestyle among $0-11$ year olds, additionally observed that socioeconomic background was a significant factor in socialization: training itself was most effective among children from high socioeconomic tiers and nuclear families, while among those from lower socioeconomic tiers other social resources parents, siblings, relations, friends and physical education teachers were more influential in socialization.

Sporting activities completed in the form of physical education lessons appear to significantly contribute to the development of self-confidence and personality in children and adolescents (Sunay \& Sunay, 1995). In another study assessing the effect of physical education training on 11-13 year olds, one of the four factors deemed to have a determining influence on student status was personality (Brock, Rovegno \& Oliver, 2009). A meta-analysis by Poropat (2009: 2014) showed a relationship between personality and academic success.

In light of the above findings and those of similar studies, it appears sport has an effect on personality development in adolescents and children. Based on this proposed correlation, the present study investigates the question, "Does basic tennis training have an effect on personality development in children and adolescents?"

This study uses the Five Factor Personality Model as the basis for measuring the effect of basic tennis training on personality development among 9-11 year olds. The research plan can be subdivided into three stages: initial tests, application of program and final tests.

\section{Method}

\subsection{Research Desing}

This research was completed using a single-group pre-test/post-test design from pre-trial models wherein a group of randomly selected volunteers were administered a pre-test, then after the application of independent variables, a post-test was administered (Karasar, 2011).

Volunteers submitted a health report and electrocardiogram (ECG) to ensure there were no pre-existing impediments to their participation. Their height and weight were recorded, and the pre-test - the PERI personality inventory-was administered. Next, participants undertook 12 weeks of basic tennis training, one hour each Saturday and one hour each Sunday, for a total of 24 hours of training. The regimen was based on the training model published for coaches by the Turkish Tennis Federation (TTF) (1999), which based its curriculum on expert opinion. Finally, the PERI personality scale was re-administered as a post-test. The tests, measurements and basic tennis training were all implemented by four academicians (including one medical doctor). 
The training did not include any specific curriculum relating to personality. Also, to avoid weather disruptions and ensure continuity, training activities were completed in an enclosed sports hall. The training curriculum is outlined on Table 1.

Table 1. 12-week basic tennis training program

\begin{tabular}{|c|c|c|c|c|c|}
\hline Week & Activity focus & Saturday & Participants & Sunday & Participants \\
\hline 1 & Hand-eye coordination work & 1 hour & 8 & 1 hour & 8 \\
\hline 2 & Hand-eye coordination work & 1 hour & 8 & 1 hour & 8 \\
\hline 3 & Forehand stroke work & 1 hour & 8 & 1 hour & 7 \\
\hline 4 & Forehand stroke work & 1 hour & 7 & 1 hour & 8 \\
\hline 5 & Backhand stroke work & 1 hour & 8 & 1 hour & 8 \\
\hline 6 & Backhand stroke work & 1 hour & 8 & 1 hour & 7 \\
\hline 7 & Forehand and Backhand stroke work & 1 hour & 8 & 1 hour & 8 \\
\hline 8 & Volley and Service work & 1 hour & 7 & 1 hour & 8 \\
\hline 9 & Volley and Service work & 1 hour & 8 & 1 hour & 8 \\
\hline 10 & Service and Smash work & 1 hour & 8 & 1 hour & 8 \\
\hline 11 & Service and Smash work & 1 hour & 8 & 1 hour & 7 \\
\hline 12 & Mini tennis tournament & 1 hour & 8 & 1 hour & 8 \\
\hline
\end{tabular}

\subsection{Participant}

The research group was created using the Simple Random Sampling method from among element sampling methods. The Simple Random Sampling method gives all elements within a sampling space an equal chance of being chosen (Karasar, 2011). The research was completed in Çanakkale, Turkey in 2015 and included a total of eight volunteers three boys and five girls aged from 9-11 years, who had no health impediments, and whom had never received tennis training nor played any other sport.

Table 2. Height, weight and age descriptive statistics of participants

\begin{tabular}{lccc}
\hline \multicolumn{1}{c}{ Variable } & n & Mean & Sd \\
\hline Age & & 10.3 & 0.8976 \\
Height & 8 & 139.87 & 11.7161 \\
Weight & & 37.34 & 12.1385
\end{tabular}

The mean age of participants was $10.3(\mathrm{Sd}=0.8976)$ years, mean height was $139.87(\mathrm{Sd}=11.7161) \mathrm{cm}$ and mean weight $37.34(\mathrm{Sd}=12.1385) \mathrm{kg}$.

\subsection{Data Collection Tool}

The Personality Inventory (PERI) was used to assess personality traits, with weight and height data collected to quantify physical characteristics.

The PERI (Sevinç, 2005) was developed according to Five Factor Personality Theory and measures the five main personality traits (openness to experience, sense of responsibility, extraversion, compatibility, emotional balance). The inventory employs a five-point Likert scale (5: definitely agree, 1: definitely disagree) and includes a total of 25 statements (five statements for each trait). The inventory also records information such as the age, sex, sporting history and health status of participants. Data collection took place through face-to-face interviews, with both the pre-test and post-test being administered by an academician.

\subsection{Data Analysis}

The data collected was uploaded to a computer environment, with mean calculations used for descriptive statistics and the Wilcoxon test used to identify differences between the pre- and post-tests. The level of significance was accepted as 0.05 .

\section{Results}

Table 3. Pre-test/post-test mean points for participant personality traits

\begin{tabular}{lllllll}
\hline \multicolumn{1}{c}{ Personality Trait } & \multicolumn{1}{c}{ Test } & N & Min. & Max. & Mean & Sd \\
\hline \multirow{2}{*}{ Openness to Experience } & Pre-Test & \multirow{2}{*}{8} & 2.80 & 4.00 & 3.22 & .446 \\
& Post-Test & & 3.80 & 4.80 & 4.00 & .338 \\
Extraversion & Pre-Test & \multirow{2}{*}{8} & 3.50 & 5.00 & 4.06 & .438 \\
\multirow{2}{*}{ Emotional Balance } & Post-Test & & 2.50 & 4.50 & 3.18 & .678 \\
& Pre-Test & \multirow{2}{*}{8} & 1.33 & 2.67 & 1.91 & .462 \\
Compatibility & Post-Test & & 1.67 & 2.33 & 2.08 & .292 \\
\multirow{2}{*}{ Sense of Responsibility } & Pre-Test & \multirow{2}{*}{8} & 3.00 & 5.00 & 4.07 & .631 \\
& Post-Test & & 3.00 & 4.40 & 3.97 & .433 \\
& Pre-Test & \multirow{2}{*}{8} & 1.80 & 4.00 & 3.12 & .716 \\
& Post-Test & & 3.00 & 4.20 & 3.72 & .452 \\
\hline
\end{tabular}

Participants appeared to possess the personality trait of openness to experience at "not effective or low" levels $(\overline{\mathrm{X}}=3.22)$ on the pre-test and at "effective or high" levels $(\overline{\mathrm{X}}=4.00)$ on the post-test. While the personality trait of extraversion was at 
"effective or high" levels $(\overline{\mathrm{X}}=4.06)$ on the pre-test, if was at "not effective or low" levels $(\overline{\mathrm{X}}=3.18)$ on the post-test. When the points for the personality trait of emotional balance were assessed on pre- $(\overline{\mathrm{X}}=1.91)$ and post-tests $(\overline{\mathrm{X}}=2.08)$, it appeared to be at "not effective or very low" levels; this was the lowest result of the five personality traits measured. The compatibility personality trait was at "effective or high" levels $(\overline{\mathrm{X}}=4.07)$ on the pre-test and at "partially effective or circumstantial" levels $(\overline{\mathrm{X}}=3.97)$ on the post-test. It appeared participants possessed the personality trait of sense of responsibility at "not effective or low" levels $(\overline{\mathrm{X}}=3.12)$ on the pre-test and at "partially effective or circumstantial" levels $(\overline{\mathrm{X}}=3.72)$ on the post-test.

The mean calculations for the personality traits of openness to experience, emotional balance and sense of responsibility were higher on the post-test than the pre-test, while the mean calculations for the personality traits of extraversion and compatibility were lower on the post-test than the pre-test.

Table 4. Differences in pre-test and post-test on the Wilcoxon test

\begin{tabular}{|c|c|c|c|c|}
\hline Personality Trait & Test & $\mathbf{N}$ & $\mathbf{Z}$ & $\mathbf{p}$ \\
\hline Openness to Experience & $\begin{array}{l}\text { Pre-test } \\
\text { Post-test }\end{array}$ & 8 & -2.388 & $.017 *$ \\
\hline Extraversion & $\begin{array}{l}\text { Pre-test } \\
\text { Post-test }\end{array}$ & 8 & -2.375 & $.018^{*}$ \\
\hline Emotional Balance & $\begin{array}{l}\text { Pre-test } \\
\text { Post-test }\end{array}$ & 8 & -1.095 & .273 \\
\hline Compatibility & $\begin{array}{l}\text { Pre-test } \\
\text { Post-test }\end{array}$ & 8 & -.690 & .490 \\
\hline Sense of Responsibility & $\begin{array}{l}\text { Pre-test } \\
\text { Post-test }\end{array}$ & 8 & -1.614 & .106 \\
\hline
\end{tabular}

An evaluation of differences in the mean points between pre-test and post-test revealed significant differences for the personality trait subscales of openness to experience $(\mathrm{p}=0.017<0.05)$ and extraversion $(\mathrm{p}=0.012<0.018)$. These significant differences both favored the post-test. There was no significant difference found between the pre-test and post-test results for the personality traits of emotional balance $(\mathrm{p}=0.012>0.273)$, compatibility $(\mathrm{p}=0.012>0.490)$ and sense of responsibility $(\mathrm{p}=0.012>0.106)$.

\section{Discussion}

Participants exhibited the personality trait of openness to experience at "not effective or low" levels $(\overline{\mathrm{X}}=3.22)$ on the pre-test and at "effective or high" levels $(\overline{\mathrm{X}}=4.00)$ on the post-test, with a significant difference in favor of the post-test. The basic tennis training is thought to have helped cultivate this personality trait among the 9-11 year olds who participated in the study. This trait is associated with the ability to produce new ideas, have a variety of areas of interest, be creative and not have fixed ideas. Planned and programmed activities with a defined aim appear to have a positive effect on adolescents' identity and sense of self (Coatsworth et al., 2005; Gilman, Meyers \& Perez, 2004). A strong relationship was also found between academic success and these personality traits among middle school students in research by Porpat (2014).

The personality trait of extraversion among participants was at "effective or high" levels on the pre-test and at "not effective or low" levels on the post-test, with the difference significantly favoring the pre-test. Participants with this personality trait can be described as individuals who are not sufficiently social, doubt themselves at times, find it difficult to protect their interests and do not show sufficient empathy to others. Morgan suggested that physical activity did not change continuous variables like extraversion and introversion (see Koruç, Bayer, 2004), and there are studies that find a positive relationship between extraversion and sporting activity (Bruijn, Kremers, Mechelen \& Brug, 2005). However, other studies have found that sports do affect the personality trait of extraversion. Research by Bayer (2003) observed that women who participated in sports from a young age were more extraverted than those who participated at an older age. In a study researching the effect of sport on social development in young people aged 6-15 years, participating in sport was found to contribute positively to social development (Er, Çamliyar, Çobanoğlu \& Er, 1999). Participation in sporting activities appears to affect the social development of students (Özçelik, 2007), and parents reportedly believe in the positive contribution of sport to development as well (Taşkıran, Selçuk \& Doğar, 2014). The results of this research may be due to the fact that participants were receiving sports training for the first time, had entered a new social environment and received training in the non-team sport of tennis.

The mean calculation indicated that the personality trait of emotional balance was at "not effective or very low" levels on both the pre-test $(\overline{\mathrm{X}}=1.91)$ and post-test $(\overline{\mathrm{X}}=2.08)$. Participants had the lowest mean points for this personality trait. This result means that participants may describe themselves as having a negative disposition, being easily aggravated and having high levels of anxiety. This may be due to the fact that participants were in the early adolescent period, had not received previous sports training, were trained in the individual and highly technical sport of tennis; that is, they may have 
experienced a lack of success due to insufficient motor skills. Studies are available showing that sporting activity has positive effects on the personality trait of emotional balance. In a group of young people aged 6-14 years with hyperactivity and behavioral disorders, depression and anxiety, participation in sports was clearly seen to reduce symptoms (Kiluk, Weden \& Culotta, 2009). Research by Berger and Owen (1983) on college students observed that students participating in swimming lessons had less anger, worry, depression and mental confusion compared to before the lessons. It appears that in treatment of the typical adolescent problems of anxiety, aggressiveness, role and identity confusion, a variety of artistic activities are effective in reducing resistance to treatment (Angyal et al., 2003). With structured environments and programs, participation in activities with a clear aim and organized sports appears to have positive effects on the emotional health of adolescents (Alpaslan, 2012).

The personality trait of compatibility was at "effective or high" levels $(\overline{\mathrm{X}}=4.07)$ on the pre-test and at "partially effective or circumstantial" levels $(\overline{\mathrm{X}}=3.97)$ on the post-test. Though the mean score on the post-test fell, the difference was not significant. Thus it appears that basic tennis training of 9-11 year olds does not contribute to the traits of being helpful, sharing, thinking of others and compatability. This may be due to the fact that tennis is an individual sport, or because the training period was limited to 12 weeks. Some studies show that sporting activity develops the trait of compatibility. Research by Küçük and Koç (2015) showed that while team sports facilitate the development of cooperation skills, individual sports facilitate the development of personal discipline. Angyal et al. (2003), in a study related to the typical adolescent problem of compatibility, found that during a variety of artistic activities a process of compliance began to develop between adolescents and their families and peers. The results of research by Jones (2005) showed that physical education lessons affected character development. Additionally it appears that middle school physical education and sports activities contribute to behavior appropriate to societal values, culture and morals, as well as compliant behavior in social environments (Akınc1, 2007).

The mean points for the personality trait of sense of responsiblity was at "not effective or low" levels $(\bar{X}=3.12)$ on the pre-test and "partially effective or circumstantial" levels $(\overline{\mathrm{X}}=3.72)$ on the post-test. While the results favored the post-test, the difference was not significant. Thus tennis training among 9-11 year olds appeared to help equip them with the skills to cope with difficulty, care about details, act carefully and after planning, and to be disciplined. Studies on the effects of sport on personality have shown that it facilitates personal discipline and increases courage (Küçük \& Koç, 2015). There is a strong relationship between the academic success of middle school children and the personality trait of sense of responsibility (Poropat, 2009; Poropat, 2014), and it appears that physical education and sporting activities help middle school-aged children develop a sense of responsibility (Akınc1, 2007).

\section{Conclusion}

Basic tennis training appeared to affect the personality development of children in the present study. According to the Five Factor Personality Model, tennis training for 9-11 year olds was observed to develop the traits of being an individual who produces new ideas, has a variety of areas of interest, is creative, does not have fixed ideas, is not pessimistic, does not anger easily, has low levels of anxiety, struggles against difficulties, pays attention to detail, acts after planning and is disciplined. However, tennis training was not effective on the personality traits of extraversion and compatibility, and even negatively affected them. Among the reasons for this may be that participants were receiving tennis training for the first time, tennis is a racquet sport requiring high technical skills, participants were in the early adolescent period, and because of the duration, hours and frequency of basic tennis training given. In consideration of these results, the development of a study with experimental and control groups, involving different age groups, with participants who both have and have not received sports training, playing different sports, and with a program of longer duration and more frequent intervals is suggested in order to reach more conclusive .

\section{Acknowledgments}

This study was supported as an "Independent Research Project (Project ID: 559)" by Çanakkale Onsekiz Mart University Scientific Research Project Coordination Unit. Ethical Considerations Permission to conduct the research was granted by the Çanakkale Onsekiz Mart University Health Sciences Institute Clinical Research Ethics Committee.

\section{References}

Akınc1, A.Y. (2007). Ortaöğretim kurumlarında beden eğitimi ve spor etkinliklerinin, sosyalleşme süreci ve şahsiyetin oluşmasinda katkısı. Yayımlanmamış Yüksek Lisans Tezi, Dumlupınar Üniversitesi, Kütahya.

Alpaslan, A. H. (2012). Ergen ruh sağlığı ve spor. Kocatepe Medical Journal, 13, 181-185.

Angyal, V., Jurta, P., Toth, A., Kovacs, M., \& Gadoros, J. (2003). Chalk circle, creative art therapeutic workshop for adolescents. 12th International Congress European Society for Child and Adolescent Psychiatry. September 28th October 1st, 2003. Paris: France. European Child \& Adolescent Psychiatry, 12(Suppl 2), 133-134. http://dx.doi.org/10.1007/s00787-003-1201-x 
Bayer, P. (2003). Spor yapan ve yapmayan bayanların kişilik özeliklerinin karşılaştırılması. Hacettepe J. of Sport Sciences., 14(3), 133-143.

Berger, B. G., \& Owen, D. R. (1983). Mood alteration with swimming: Swimmers really "do feel Better". Psychosomatic Medicin., 45(5), 425-433.

Brock, S. J., Revegno, I., \& Oliver, K. L. (2009). The influence of student status on student interactions and experiences during a sport education unit. Physical Education and Sport Pedagogy, 14(4), 355-375. http://dx.doi.org/10.1080/17408980802400494

Bruijn, G. J., Kremers, S. P. T., Mechelen, W., \& Brug, J. (2005). Is personality related to fruit and vegetable intake and physical activity in adolescents? Health Education Research Theory \& Practice, 20(6), 635-644.

Celestin-Westreich, S., Celestin, L. P., \& Ponjaert-Kristoffersen, I. (2013). Maltreated children's expression of traumatic family experiences. 12th International Congress European Society for Child and Adolescent Psychiatry. September 28th-October 1st, 2003 Paris: France. European Child \& Adolescent Psychiatry, 12(1/2), 42-43. http://dx.doi.org/10.1007/s00787-003-1201-x

Coatsworth, J. D., Sharp E. H., Palen, L., Darling, N., Cumsille, P., \& Marta, E. (2005). Exploring adolescent self-defining leisure activities and identity experiences across three countries. International Journal of Behavioral Development, 29(5), 361-370. http://dx.doi.org/10.1080/01650250500166972

Dinçel, E. (2006). Ergenlik dönemi gelişimsel ödevleri ve psikolojik problemler. Yayımlanmamış Yüksek Lisans Tezi, Ankara Üniversitesi, Ankara.

Endresen, I. M., \& Olweus, D. (2005). Participation in power sports and antisocial involvement in preadolescent and adolescent boys. Journal of Child Psychology and Psychiatry, 46(5), 468-478. http://dx.doi.org/10.1111/j.1469-7610.2005.00414.x

Er, G., Çamlıyer, H., Çobanoğlu, G., \& Er, N. (1999). Spor etkinliklerinin çocuk ve ergenlerde davranış ve sosyal gelişim üzerine etkileri. $B E S B D, 3,29-38$.

Fields, L., \& Prinz, R. J. (1997). Coping and adjustment during childhood and adolescence. Clinical Psychology Review, 17(8), 937-976. http://dx.doi.org/10.1016/S0272-7358(97)00033-0

Gilman, R., Meyers, J., \& Perez, L. (2004). Structured extracurricular activities among adolescents: Findings and implications for school psychologists. Psychology in the Schools, 41(1), 31-41. http://dx.doi.org/10.1002/pits.10136

Hasırc1, S. (2013). Sport and Personality. Dia Gaste, 27. URL: http://www.diegaste.de/gaste/ diegaste-sayi2712.html. erişim tarihi: 24 Aralık 2013.

Jones, C. (2005). Character, virtue and physical education. European Physical Education Review, 11(2), 139-151. http://dx.doi.org/10.1177/1356336X05052893

Karasar, N. (2011). Bilimsel araştırma yöntemleri. Ankara: Nobel Yayıncılık.

Kiluk, B. D., Weden, S., \& Culotta, V. P. (2009). Sport participation and anxiety in children with ADHD. J Atten Disord., $12,499-506$.

Korkmaz, N. H. (2007). Yaz spor okulları ile çocukların benlik saygısı arasındaki ilişki. Uludă̆ Üniversitesi Ĕgitim Fakültesi Dergisi, 20(1), 49-65.

Koruç, Z., \& Bayar, P. (2004). Egzersizin depresyon tedavisindeki yeri ve etkileri. Spor Bilimleri Dergisi, 15(1), 49-64.

Küçük, V., \& Koç, H. (2015). Psiko-sosyal gelişim süreci içerisinde insan ve spor ilişkisi. Dumlupınar Üniversitesi Sosyal Bilimler Dergisi., 10(10), 1-11.

Özcebe, H. (2002). Birinci basamakta adolesan sorunlarına yaklaşım. Sürekli Tip Eğitimi Dergisi, 11(10), 374-377.

Özçelik, E. (2007). Öğrencilerin sosyalleşmesinde beden eğitimi dersinin rolü. YayımlanmamışYüksek Lisans Tezi, Beykent Üniversitesi: İstanbul.

Poropat, A. E. (2009). A meta-analysis of the Five-Factor Model of personality and academic performance. Psychological Bulletin, 135(2), 322-338. http://dx.doi.org/10.1037/a0014996

Poropat, A. E. (2014). A meta-analysis of adult-rated child personality and academic performance in primary education. British Journal of Educational Psychology, 84, 239-252. http://dx.doi.org/10.1111/bjep.12019

Sevinç, L. (2005). PERI Kişilik Envanteri Teknik Kitapcığı. İstanbul: Assessment Systems Publications.

Shiner, R., \& Caspi, A. (2003). Personality differences in childhood and adolescence: Measurement, development, and 
consequences. Journal of Child Psychology and Psychiatry, 44(1), 2-32.

Soğat, A. (2007). Spor yapan ve yapmayan 11-12 yaş grubu çocuklarda bazl fiziksel özelliklerin araştırlması. Yayımlanmamış Yüksek Lisans Tezi, Dumlupınar Üniversitesi, Kütahya.

Stuij, M. (2015). Habitus and social class: A case study on socialisation into sports and exercise. Sport, Education and Society, 20(6), 780-798. http://dx.doi.org/10.1080/13573322.2013.827568

Sunay, Y., \& Sunay, H. (1995). Lise öğrencilerinin beden eğitimi dersinden beklentileri ve beklentilerinin gerçekleşme düzeyi. Performans, 3, 79-97.

Taşkıran, C., Selçuk, H. M., \& Doğar, Y. (2014). The opinion of primary school student's parents about the effects of physical education on socialization process The Journal of Academic Social Science Studies, 26(II), 159-166. http://dx.doi.org/10.9761/JASSS2395

TTF [Türkiye Tenis Federasyonu] (1999). Tenise Başlarken. Ankara: Türkiye Tenis Federasyonu Yayınları. Yayın No. 1. Yanbastı, G. (1996). Kişilik Kuramları. İzmir, Ege Üniversitesi Eğitim Fakültesi Yayınları. 